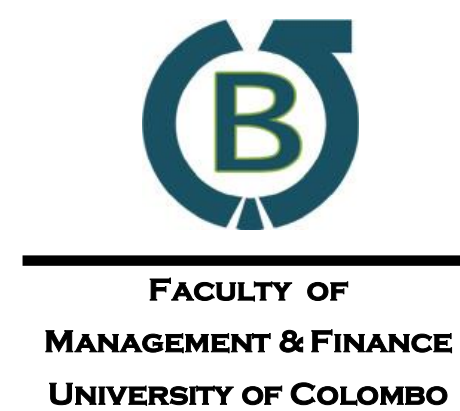

UNIVERSITY OF COLOMBO
Vol. 04, No. 01, June 2013
Colombo

Business

Journal

International Journal

of Theory \& Practice

\title{
The Impact of Parliamentary and Presidential Elections on Stock Returns in Colombo Stock Exchange (CSE)
}

\author{
A. M. C. P. Attapattu ${ }^{a}$, P.S.M. Gunaratne \\ ${ }^{a}$ Department of Business Economics, University of Colombo, Sri Lanka \\ ${ }^{b}$ Department of Finance University of Colombo, Sri Lanka
}

\begin{abstract}
The research issue of this study is whether political events result in structural shift in stock return in CSE. The purpose of this study is to find whether there is a predictable pattern in the market and any structural shift in the market response to events of election announcements and release of election results. If a predictable pattern exists, the purpose is to identify any economically viable arbitrage strategies arising out of special pattern of market behavior in relation to events of election announcements and release of election results. To achieve this objective independent analytical devices are used in this research under event study methodology. According to the analysis of results, the formation of market sentiments in relation to election related events can be summarized as follows. If the announcement is taken place under a UNP dominant government, market seems to create negative sentiments around the events. However within few days of announcement market again gains the profit of the loss initially took place with the announcement. According to this speculative behavior, an investor who is having a prior knowledge about the announcement may sell the stocks well in advance of the election announcement in order to avoid subsequent losses taking place in the market. If the announcement is taken place under a SLFP dominant government, market seems to create positive sentiments around the events. According to this speculative behavior, an investor who is having a prior knowledge about the announcement may buy the stocks well in advance of the election announcement in order to sell and earn profit during the post event window. If a market friendly government comes to power with the release of election results, market seems to create positive sentiments, and if a less market friendly government comes to power market responses negatively.
\end{abstract}

Keywords: Market friendly government, Elections, Structural shift, Events

${ }^{\mathrm{a} C}$ Corresponding author: cpatapattu@gmail.com 


\section{Introduction}

Stock market plays a vital role in modern economies. It facilitates the allocation of resources among various investments and ensures a market for securities of publicly listed companies. In Sri Lanka the history of stock market operation goes back to $18^{\text {th }}$ century. However, with the introduction of open market economic policies in late 1970s, Sri Lankan share market have developed rapidly in terms of both number of companies listed and total market capitalization.

With the introduction of open market economic policies in late 1970s, successive governments in Sri Lanka paid more attention to market friendly policies encouraging private investments in the country. However, the observations of past stock price movements in the Colombo Stock Exchange in relation to political changes and changes in the security situation showed its quick response to such changes over short span of time.

Even though, the economic stability is always expected by investors through right political changes, history proves that the political events and crises affect the economic conditions of the country both in a favorable and unfavorable manner. Some economic events might be triggered due to non-political reasons as well. However, according to Freedman (1997), Asia was hit with a severe economic crisis in 1997 and 1998. He further pointed out that most countries in the region were faced with massive currency fluctuations, banking crises, and plummeting stock markets and these economic problems were compounded by political turmoil. Given past experiences in Asia of massive financial difficulties coupled with political upheaval, Kelin, Misrach \& Murphy (1991) have studied how announcements of economic data affect financial market variables. They found a strong relationship between announcements of economic data and their effect on financial market variables. Bilson, Brailsford \& Hooper (2002) suggest that stock prices are specifically sensitive to the political events. In any given democratic country, major elections (announcement of elections and the announcement of election results) can be considered as major political events. Especially elections to elect the head of state of the government (president) and elections of law makers (parliamentary elections) are very significant in this regard. In Sri Lanka too, these two elections (presidential and parliamentary) are considered as important elections in many respects. These two institutions are important to the investor as they can jointly and individually make their impact to the economy and financial markets through policy interventions and introduction of new practices. This study aims to study the relation between major elections and stock markets in the context of Sri Lanka.

\subsection{Objectives of the Study}

1. To investigate the structural shift in the market in response to major political events of the announcements of elections and release of the election results.

2. To examine whether there is a predictable pattern in stock return in relation to the announcements of elections and the release of election results.

3. To identify economically viable trading strategies arising out of the patterns in relation to both the announcements of election and the release of election results.

\section{Literature Review}

\subsection{Politics and Stock Markets}

The influence of politics cannot be separated from almost of all economic, social and cultural affairs in a democratic country. The politicians and political parties have enormous powers to 
influence such affairs through legislations, policy and administrative interventions. As the performance of stock market is considered as a reflection of economy, any influence made by politics on the economy would ultimately be reflected through performance of the stock market. Previous studies in this regard can be broadly divided into two categories. One category of studies pays attention on different political regimes (governments) and their impact on stock market. The others have looked at the influence on elections on the performance of stock market which is the theme of this study as well.

\subsection{Stocks Returns and Different Governments}

Several studies (Huang, 1985; Niederhoffer, Gibbs\& Bullock, 1970) highlighted that one of the more surprising developments in stock market, is the discovery of a number of patterns in security return. These patterns are remarkably consistent, statistically significant, and they suggest that these patterns facilitate in developing profitable trading rules. This indicates that the political uncertainty takes many different shapes and forms; the government changes in the domestic and foreign policy. Further, Huang (1985) emphasizes that historically, higher average returns have been obtained during democratic administrations than during republican administrations. Niederhoffer et al. (1970) concluded that if a republican bias were justified, one would expect the market to perform significantly better during a republican administration than a democratic administration. Riley and Luksetich (1980) concluded that the market indicated positive direction to Republican victory and negative to Democratic victory. Huang (1985) declared that the results show the basic pattern of higher returns in years 3 and 4 for both political parties in USA. Based on the findings the investors can take decisions in their profit making as short term or long term strategies and to decide which strategy is most fruitful out of trading rule and buy and hold. According to Niarchos \& Alexakist (2003) trading rule was formed that yielded higher profits than the buy and hold strategy. Freedman (1997) emphasized that the "candidates who campaigned for greater political reform and openness have triumphed over the others". Lopez (2002) states that the "composition of a legislator's parliamentary rights determines which groups he can service with the least cost". Giving an example Lopez (2002) stressed that a legislator on the agriculture committee is better suited than a legislator on the armed services committee to imparting rents on farmers. The legislator's standing among voters and other unorganized interests also determines which groups he can service with the least cost. This has an impact on the one with higher poll support or greater margin of victory though two legislators representing similar constituencies. Johnson, Chittenden, and Jenson (1999) found that the returns to large cap stocks are not statistically different in republican or democratic administration. Also they indicate that the returns to small- cap stocks are substantially higher during democratic administration. In that study, time period covered presidents elected in seventeen different elections, eight Republican and nine Democratic. Further Johnson et al. used both nominal returns and inflation adjusted returns in their study. From their findings they declared that if inflation was significantly higher during Democratic or Republican administration, nominal returns did not properly reflect the real returns actually earned by investors. They also reexamine the relationship between stock returns in the first and the second halves of presidential terms. Their finding generally support prior research that shows stocks returns are significantly higher in the second half of the term. The return differences persist across parties but are stronger during Democratic administration. According to Huang (1985) Common stock returns and presidential elections has shown combined returns for years 1 and 2 and years 3 and 4 of the cycle. From the findings of the empirical study he emphasizes that the existence of an election cycle is much more apparent in every one of the six periods and is fairly strongly 
corroborated by standard statistical tests. Allvine \& Neill (1980) discussed the concept of a four year political business cycle based on the strong incentive for politicians to stimulate the economy prior to a presidential election and to pursue deflationary policies following election. Freedman further says that most countries in the region were faced with massive currency fluctuations, banking crises, and plummeting stock markets. Economic problems were compounded by political turmoil. Given past experiences in Asia of massive financial difficulties coupled with political upheaval. They investigated the relationship between economic crises and political change. According to several studies (Chan \& Wei, 1996; Bittlingmayer, 1998) new political information affects the national economy's future. Exploring complicated relationship between stock market and political behavior using statistical methods is one of the most exciting issues for both academicians and investors. Some studies (Foerster, 1994; Foerster \& Schmitz, 1997) supported the presidential election cycle that US stock markets make larger gains in the third and fourth year of a presidential term, while average returns in the second year are negative. Pantzalis, Stangeland \& Turtle (2000) examined how various types of political information impact on stock markets. Further empirical studies (Harms, 2002; Lin \& Wang, 2007) concluded that political information make an impact on stock returns. According to Freedman (1997) past experiences in Asia of massive financial difficulties coupled with political upheaval and political uncertainty is associated with national elections. National elections are the major political events for re-distribution of political power in a domestic system and it has important implications for the future political and economic course of a country.

There is limited research and literature on CSE with regard to political capital. Concentrating the above existing literature, the researcher uses all share price index (ASPI), Milanka price index (MPI) and indexes of six sectors which consist of highest market capitalization from 1990 to 2005 to study structural shifts and behavior of stock return in terms of parliamentary and presidential elections to develop profit making strategies.

\section{Methodology}

\subsection{Classification of Elections}

A structural change would communicate the level of market efficiency in relation to a particular event. In an efficient market all information is supposed to be distributed symmetrically. Therefore, when a new piece of information comes to the market it could make a surprise and the market would move to a new equilibrium making a structural change in the flow of data depending on the intensity of the particular piece of information. However, in practice it might be difficult to assume that the market is always efficiently moving to a new equilibrium due to the nature of the arrival of new information. Information might leak to the market prior to the event. On the other hand, market would not adjust to a new equilibrium within one or two days. It would take time for full adjustment. Again pattern of price responses would be different from one election to another depending on the new political party who is going to form the government after the election. Most of the time governments are formed by UNP or SLFP lead collusion group of political parties. With the election, the new government formed would be again either UNP or SLFP. In this study, it would most probably help to find certain predictable pattern of stock returns connected to the announcement of election and the announcement of election results, whether profit making strategies could be developed for these time windows. 


\subsection{Event Window and Investigation Window}

In event studies, the event window is defined in order to capture the level of surprise brought by the event to the market. In Sri Lanka, elections are announced in late evening or midnight, therefore it could bring any surprise to the market on the first market day after the announcement. Therefore the researcher defines the first market day after the announcement of the election as the event window in relation to the announcement of election. The process taken place in relation to the release of election results is somewhat different. Election results are announced on piecemeal manner starting on late night on Election Day. If an election is held just prior to two consecutive holidays the results would be released within two holidays. The market will react on election surprisingly on the third day from the Election Day.

However, if an election is held on a weekday investors would start to response the event from the subsequent day if the market is opened on that day. However, market response may not be limited to a single day. They may response even on the second day from the election if the market is opened. This is because election results are not fully concluded within one day after the election. In such cases two days after the election were taken as event window. Accordingly, the event window in relation to the announcement of election results may consist either one or two days after the election. Table 1 gives the spread of the event days in relation to the sample.

\section{Table 1: Spread of Event Days}

\begin{tabular}{lcccc}
\hline \multicolumn{3}{c}{ Parliamentary elections } & & \\
\hline & \multicolumn{2}{c}{ Announcement of elections } & \multicolumn{2}{c}{ Announcement of results } \\
& Announcement day & Event window & Election day & Event window \\
\hline $\mathbf{1 9 9 4}$ & 24 th June (Friday) & $27^{\text {th }}$ June (Monday) & $16^{\text {th }}$ August (Tuesday) & $22^{\text {nd }}$ August (Monday) \\
$\mathbf{2 0 0 0}$ & $18^{\text {th }}$ August (Friday) & $21^{\text {st }}$ August (Monday) & $10^{\text {th }}$ October (Tuesday) & $13^{\text {th }}$ August (Friday) \\
$\mathbf{2 0 0 1}$ & $10^{\text {th }}$ October (Wednesday) & $11^{\text {th }}$ October (Thursday) & $05^{\text {th }}$ December (Wednesday) & $07^{\text {th }}$ December (Friday) \\
$\mathbf{2 0 0 4}$ & $06^{\text {th }}$ February (Friday) & $09^{\text {th }}$ February (Monday) & $02^{\text {nd }}$ April (Friday) $^{\text {th }}$ April (Tuesday) & 0 \\
\hline
\end{tabular}

\section{Presidential elections}

Announcement of elections

Announcement of results

\begin{tabular}{lcccc} 
& Announcement day & Event window & Election day & Event window \\
\hline $\mathbf{1 9 9 4}$ & $16^{\text {th }}$ September (Friday) & 20th September (Tuesday) & 09th November(Wednesday) & 11th November (Friday) \\
$\mathbf{1 9 9 9}$ & 29th October (Friday) & 01st November (Monday) & 21st December (Tuesday) & 23rd December (Thursday) \\
$\mathbf{2 0 0 5}$ & 26th September (Monday) & 27th September (Tuesday) & 17th November (Thursday) & 21st November (Monday) \\
\hline
\end{tabular}

Source: Researcher's construction

\subsection{Analytical Techniques}

To identify the depth of surprise brought by the event, three independent analytical devices are used in this research.

i. Auto Regressive Linear Model.

ii. Multivariate Dummy Variables Regression Model

iii. Constant Mean Return Model. 
With the objective of identifying whether the election related two major events; the announcement of election and the announcement of election results causes a structural change to the flow of stock returns, the following Auto Regressive Linear Model is employed.

\subsubsection{Auto Regressive Linear Model}

$$
R_{x i}=a_{0}+a_{1} D+a_{2} A R(1)+e
$$

Where, $R_{x i}$ is Return on ASPI, $a_{0}$ is Constant, $a_{1}$ is Coefficient of Dummy variable, $a_{\mathbf{2}}$ is Coefficient of AR (1) term, $D$ is Dummy variable, $A R(1)$ is Auto Regressive (1) term and $e$ is error term.

\subsubsection{Multivariate Dummy Variables Regression Model}

$$
R_{j t}=\alpha_{j}+\beta_{j 1} R M_{t-1}+\beta_{j \mathbf{2}} R M_{t}+\beta_{j \mathbf{3}} R M_{t+1}+\sum_{k=1}^{n} \gamma_{j k} D_{k t}+\varepsilon_{j t}
$$

The above Multivariate Dummy Variables Regression Model (Chen, Bin,\& Chen, 2005) is applied to study the structural shift of MPI and the six sectors. Where, $R_{j t}$ is Return on MPI or Sectors, $\boldsymbol{\alpha}_{j}$ is Constant, $\beta_{j \mathbf{1}}, \beta_{j \mathbf{z}}, \beta_{j \mathbf{z}}$ are Coefficient of market portfolio. $R M_{t}$ is the return on ASPI on day $\mathrm{t}$, lead and lag market returns $R M_{t-1}, R M_{t+1}$ are added as explanatory variables to deal with return distributional problems associated with nonsynchronous trading, $\gamma_{j k}$ is coefficient of dummy variable, $D_{k t}$ is the dummy variable that captures the impact of event $\mathrm{k}$ on portfolio return and equals 1 if day $\mathrm{t}$ is within the event window period and 0 otherwise, and $\varepsilon_{j t}$ is an error term.

With the objective of identifying whether election related two major events; announcement of election and announcement of election results cause a behavioural change in the flow of stock returns on and around the elections, the following Constant Mean Return Adjusted Model is employed.

\subsubsection{Constant Mean Return Model}

$$
A R_{i t}=R_{i t}-A R_{\text {ie }}
$$

In the above model daily abnormal returns $\left(A R_{i t}\right)$ of stocks for any given day is measured by deducting average market return $\left(A R_{i e}\right)$ of a pre-identified estimation window from the actual return $\left(R_{i t}\right)$ on the same day. For this purpose, the estimation window of the study is set to 200 market days prior to the pre-event window (from -215 day to -16 day relative to the event). Therefore, the assumption is that any abnormal return during the investigation window is generated due to the influence made by the event. Abnormal return distribution on pre-event window would tell us the nature of the market expectation regarding the event and the prior knowledge market processes regarding the event. The distribution of AR during the post-event window would tell us the speediness of the process of price adjustment after the event. This would reveals information on the level of market efficiency as well.

Moreover, in this study cumulative Abnormal Return (AR) is estimated by using the following equation during the investigation window. 


$$
C A R_{i t}=A R_{i t}+C A R_{i(t-1)}
$$

According to the above model, cumulative abnormal return $\left(C A R_{i t}\right)$ of a stock return on any given day is found by adding the days abnormal return to the cumulative abnormal return of the previous day.

The estimation results of the above model one would help in determining whether the event causes a structural change in the flow of return data. According to 5\% significance level, if the probability value of Dummy variable is less than 0.05 , the study concludes that the event has caused a significant structural change in stock returns. If there is a statistically significant structural change in the flow of return data it could mean number of things. Simply this means the level of surprise brought by the event within the event window is high. Surprise would be due to two reasons. It can be due to either totally unexpected event by the market. On the other hand, event is expected the outcome occurred might be not in magnitude it has occurred.

\section{Data Presentation and Analysis}

\subsection{Announcement and Release of Results in Parliamentary and Presidential Election.}

Table 2: Dummy Variable Regression Models

\begin{tabular}{|c|c|c|c|c|c|c|c|}
\hline $\begin{array}{l}\text { Announcement } \\
\text { of Election }\end{array}$ & $\begin{array}{l}1994 \\
\text { Parli } \\
\text { ament }\end{array}$ & $\begin{array}{c}1994 \\
\text { Presidenti } \\
\text { al }\end{array}$ & $\begin{array}{c}1999 \\
\text { Presidenti } \\
\text { al }\end{array}$ & $\begin{array}{c}2000 \\
\text { Parliame } \\
\text { nt }\end{array}$ & $\begin{array}{r}2001 \\
\text { Parliame } \\
\text { nt }\end{array}$ & $\begin{array}{c}2004 \\
\text { Parliame } \\
n t\end{array}$ & $\begin{array}{c}2005 \\
\text { Presidenti } \\
\text { al }\end{array}$ \\
\hline ASPI & $0.001 *$ & 0.567 & 0.806 & 0.902 & $0.001 *$ & $0.000^{*}$ & 0.817 \\
\hline MPI & 0.65 & 0.942 & 0.735 & 0.968 & 0.328 & $0.000^{*}$ & 0.458 \\
\hline Bank Finance & 0.319 & 0.966 & 0.958 & 0.667 & $0.000 *$ & $0.000^{*}$ & 0.531 \\
\hline Beverage Food & 0.25 & 0.929 & 0.359 & 0.996 & 0.106 & $0.005 *$ & 0.147 \\
\hline Hotels & $0.009 *$ & 0.833 & 0.673 & 0.987 & 0.345 & 0.764 & 0.686 \\
\hline Land & 0.616 & 0.355 & 0.235 & 0.911 & $0.043 *$ & $0.031 *$ & 0.893 \\
\hline Manufacturing & 0.282 & 0.646 & $0.024 *$ & 0.461 & $0.001 *$ & $0.021 *$ & 0.106 \\
\hline Plantation & - & - & 0.95 & 0.637 & 0.238 & 0.704 & 0.923 \\
\hline Announcement & 1994 & 1994 & 1999 & 2000 & 2001 & 2004 & 2005 \\
\hline of Election Results & $\begin{array}{c}\text { Parliame } \\
\text { nt }\end{array}$ & $\begin{array}{l}\text { Presidenti } \\
\text { al }\end{array}$ & $\begin{array}{l}\text { Presidenti } \\
\text { al }\end{array}$ & $\begin{array}{c}\text { Parliame } \\
\text { nt }\end{array}$ & $\begin{array}{c}\text { Parliame } \\
\text { nt }\end{array}$ & $\begin{array}{c}\text { Parliame } \\
\text { nt }\end{array}$ & $\begin{array}{c}\text { Presidenti } \\
\text { al }\end{array}$ \\
\hline ASPI & 0.062 & 0.596 & 0.165 & $0.001 *$ & $0.000 *$ & $0.000 *$ & $0.000 *$ \\
\hline MPI & 0.28 & 0.378 & 0.667 & 0.328 & $0.042 *$ & $0.000 *$ & $0.014 *$ \\
\hline Bank Finance & $0.030 *$ & 0.613 & 0.1 & $0.000 *$ & $0.003 *$ & $0.005 *$ & $0.044 *$ \\
\hline Beverage Food & 0.337 & 0.731 & 0.123 & 0.106 & 0.102 & $0.000 *$ & 0.308 \\
\hline Hotels & $0.032 *$ & 0.253 & 0.601 & 0.345 & $0.001 *$ & 0.19 & 0.765 \\
\hline Land & 0.433 & 0.678 & 0.842 & $0.043 *$ & 0.4 & $0.050 *$ & 0.911 \\
\hline Manufacturing & 0.898 & 0.496 & 0.315 & $0.001 *$ & 0.718 & 0.284 & 0.467 \\
\hline Plantation & - & - & 0.434 & 0.238 & $0.014 *$ & 0.202 & 0.918 \\
\hline
\end{tabular}

* Significant at 5\% level

Source: Researcher's construction

Table 2 shows the results of the level of significance in Dummy variable Regression Model adopted to observe the structural shift. It indicates that the announcement of the parliamentary 
election in 1994 had made a significant impact to the returns on ASPI and Hotel sector while the announcement of election results had made a significant impact to the returns on Bank \& Finance and Hotel sectors. The announcement and the release of election results of presidential election in 1994 had not made a significant impact to the returns on ASPI, MPI and selected six sectors. The P value on manufacturing sector is highly significant to the announcement of the presidential election in 1999 and the P value on ASPI, MPI and all the six sectors is insignificant to the presidential election results. ASPI, MPI and all the six sectors had not an impact from the announcement of the parliamentary election in 2000 but the announcement of the parliamentary election results in 2000 had made a significant impact to the returns on ASPI, Bank and Finance, Land and Property, and Manufacturing. The announcement of the parliamentary election in 2001 had made a significant impact to the returns on ASPI, Bank \& Finance, Land \& Property and Manufacturing sectors. Release of election results significantly created a structural shift on ASPI, MPI, Bank \& Finance, Hotels and Plantation sectors. The P value on ASPI, MPI, Bank \& Finance, Food \& Beverage, Land \& Property and Manufacturing sectors is highly significant. It indicates that the announcement of the parliamentary election in 2004 had made a significant impact to the returns on ASPI, MPI, Bank \& Finance, Food \& Beverage, Land \& Property and Manufacturing sectors. The P value on ASPI, MPI, Bank \& Finance, Food \& Beverage and Land \& Property sectors is highly significant to the announcement of election results. The P value on ASPI, MPI and all the six sectors is insignificant to the presidential election in 2005. ASPI, MPI and Banking \& Finance sector is highly significant to the announcement of the presidential election results in 2005 .

\subsection{Patterns of Formation of Political Capital in the CSE.}

Different authors have paid attention on the formation of political capital in relation to different stock markets (Niarchos \& Alexakis, 2003). As economic policies adopted by different governments determine the freedom or space available for private investments, they play a vital role in the way of capital formation in the country. If government provides more freedom for the private investments and expects the private sector to play a vital role in economic development, such a policy would definitely encourage private investments at various levels. Government would make private investments more attractive or less attractive by enforcing new laws and regulations or changing and withdrawing existing such laws and regulations. They may reflect in the form of enforcing embargos and restrictions or liberalizing and lifting existing embargos and restrictions. In this regard they may use tax and subsidies as well. After independence, Sri Lanka has witnessed such policy shifts from government to government. A sixty year history of post independent Sri Lanka had demonstrated clear shift in policy orientation from government to government. Basically, Sri Lanka has formed two types of governments; (1) UNP led right-wing government, (2) SLFP led left-wing government. As discussed elsewhere in this study, the government formed by the UNP and allies had always been more market friendly contrast to the SLFP led government. This means that space for capital operation has been higher under UNP regime while the same has been lower under the regime formed by SLFP. However, the differences in relation to economic policies between two political parties have been reducing since 1990 for general election. Yet, investors might prefer UNP led government because their historical identities for pro market policies (Mendis, 2003). On the other hand, investors would not prefer SLFP government for less market friendly policies followed by them when they were in power. However, the opinion of general public would be different from investment community. Therefore, in this section efforts are made to any patterns in investors' behaviour in 
relation to the announcement of elections and announcement of election results. With this purpose in mind, all presidential and parliamentary elections after 1990 have been divided into two categories;

1. Announcement of elections under SLFP government and

2.Announcement of elections under UNP government.

Accordingly, the announcement of parliamentary elections 2000 and 2001, and the announcement of presidential elections in 1999 and 2005 belong to the category one as all the elections had been announced under SLFP regime. On the hand, the announcement of parliamentary elections in 1994 and 2004, and the presidential election in 1994 were announced under a UNP led government.

Figure 1: Announcement of Election under More Market Friendly Government- Cumulative

Return and Cumulative Abnormal Return on ASPI on and Around Election Announcement Day

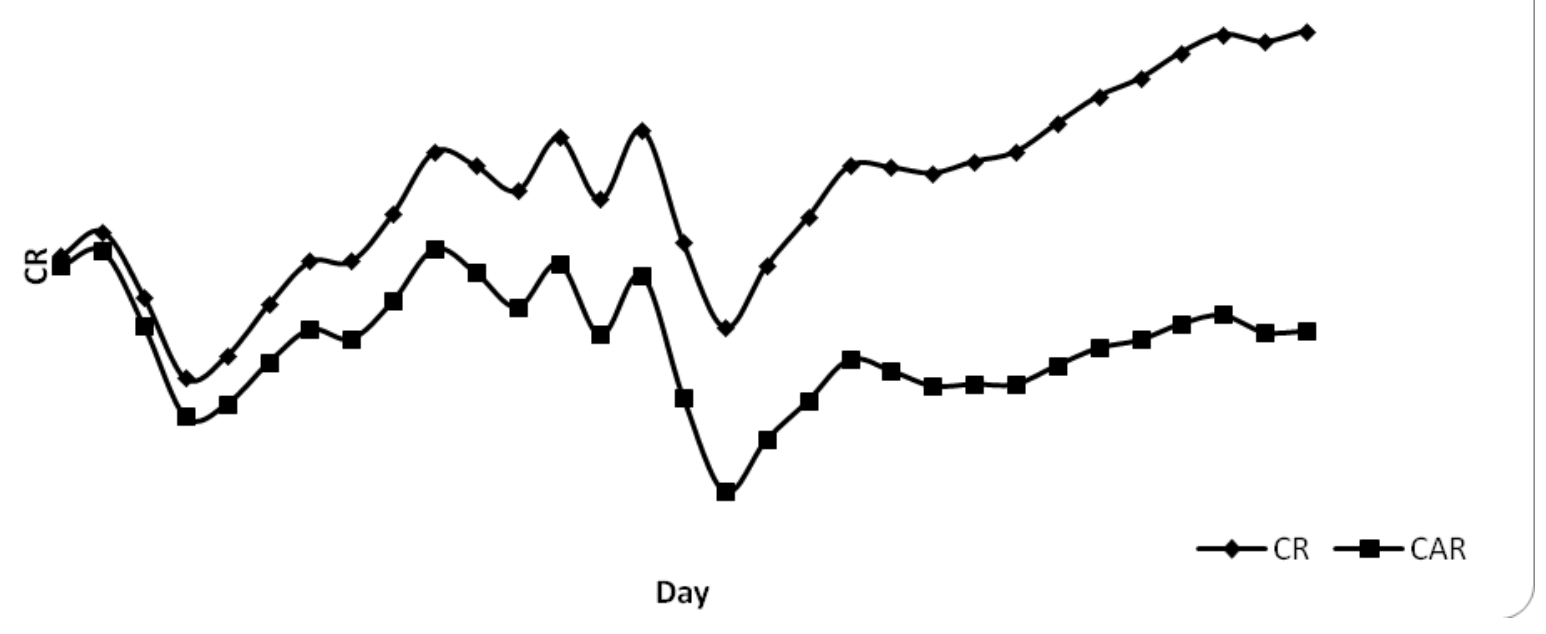

Source: Researcher's construction.

Figure 2: Announcement of Election under More Market Friendly Government- Cumulative

Return and Cumulative Abnormal Return on MPI on and Around Election Announcement Day

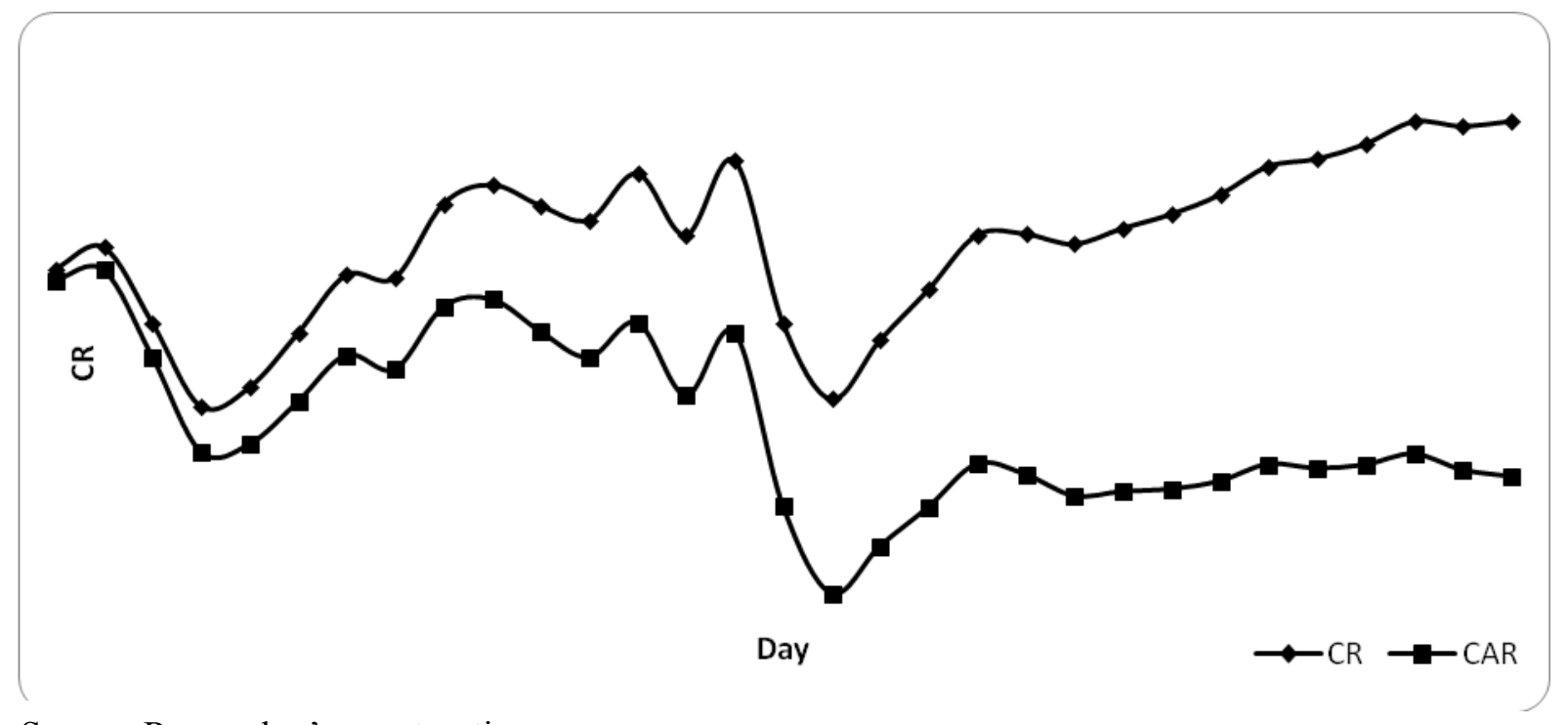

Source: Researcher's construction 
If the announcement of election is taken place under a UNP dominant government, market seems to create negative sentiments and within few days of announcement market started to gain profit showing a U turn. According to cumulative abnormal return, market had been losing 0.411 in terms of ASPI and 3.587 in terms of MPI within the investigation window in relation to their history. In relation to the test statistics, the higher values could be seen on and around the event day. This indicates that the announcement of election has created negative sentiments in the market. According to this speculative behaviour, an investor who is having a prior knowledge about the announcement may sell the stocks well in advance the election announcement in order to avoid the losses. However soon after the announcement of election selling seems not to be advisable as market gains profit within few days. If somebody wishes to get out of the market after the announcement; ideally he or she may sell the shares within +2 to +4 days as the higher positive returns belong to this period. These conclusions are based on the experience of three such events.

Figure 3: Announcement of Election under Less Market Friendly Government- Cumulative Return and Cumulative Abnormal Return on ASPI on and Around Election Announcement Day

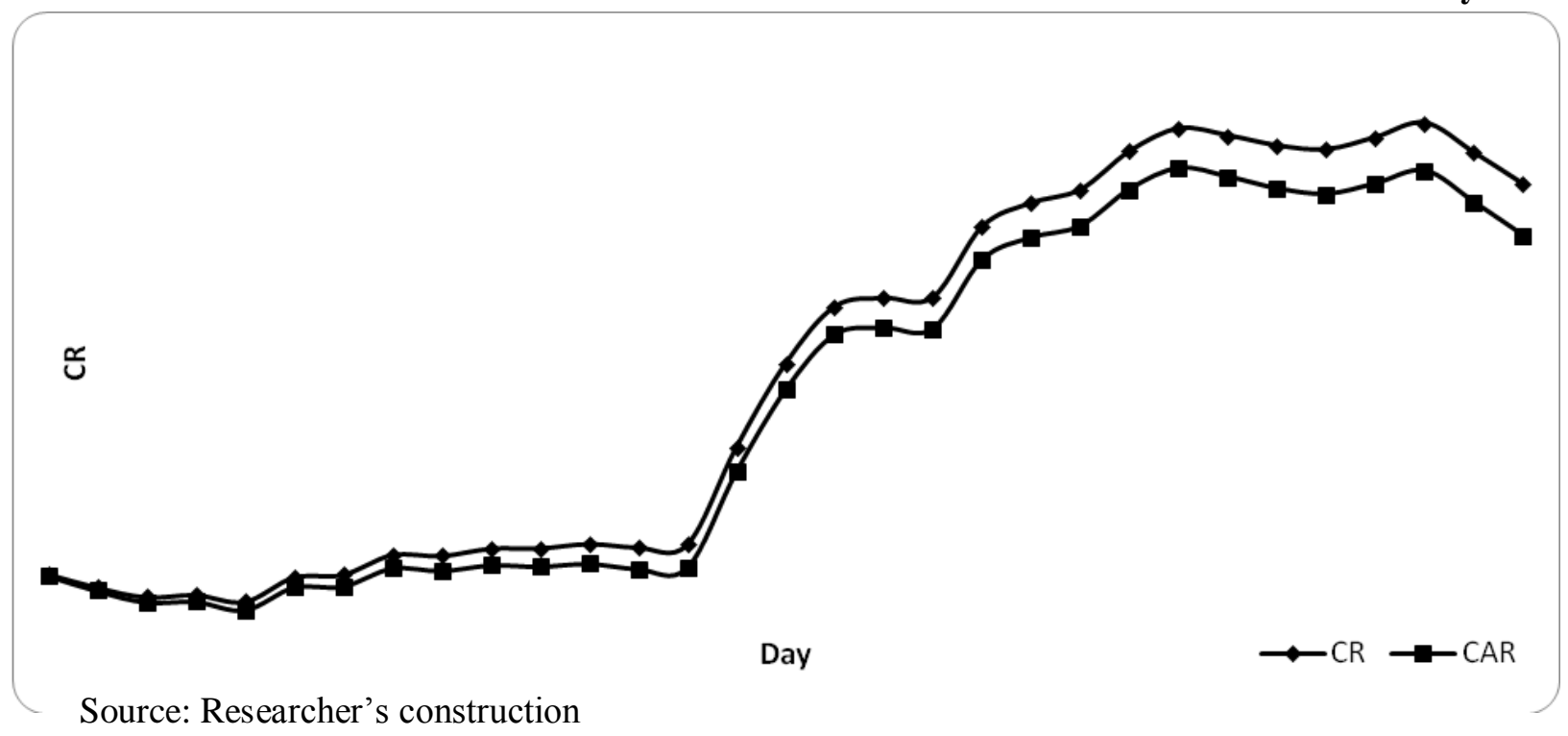

Figure 4: Announcement of Election under Less Market Friendly Government- Cumulative Return and Cumulative Abnormal Return on MPI on and Around Election Announcement Day

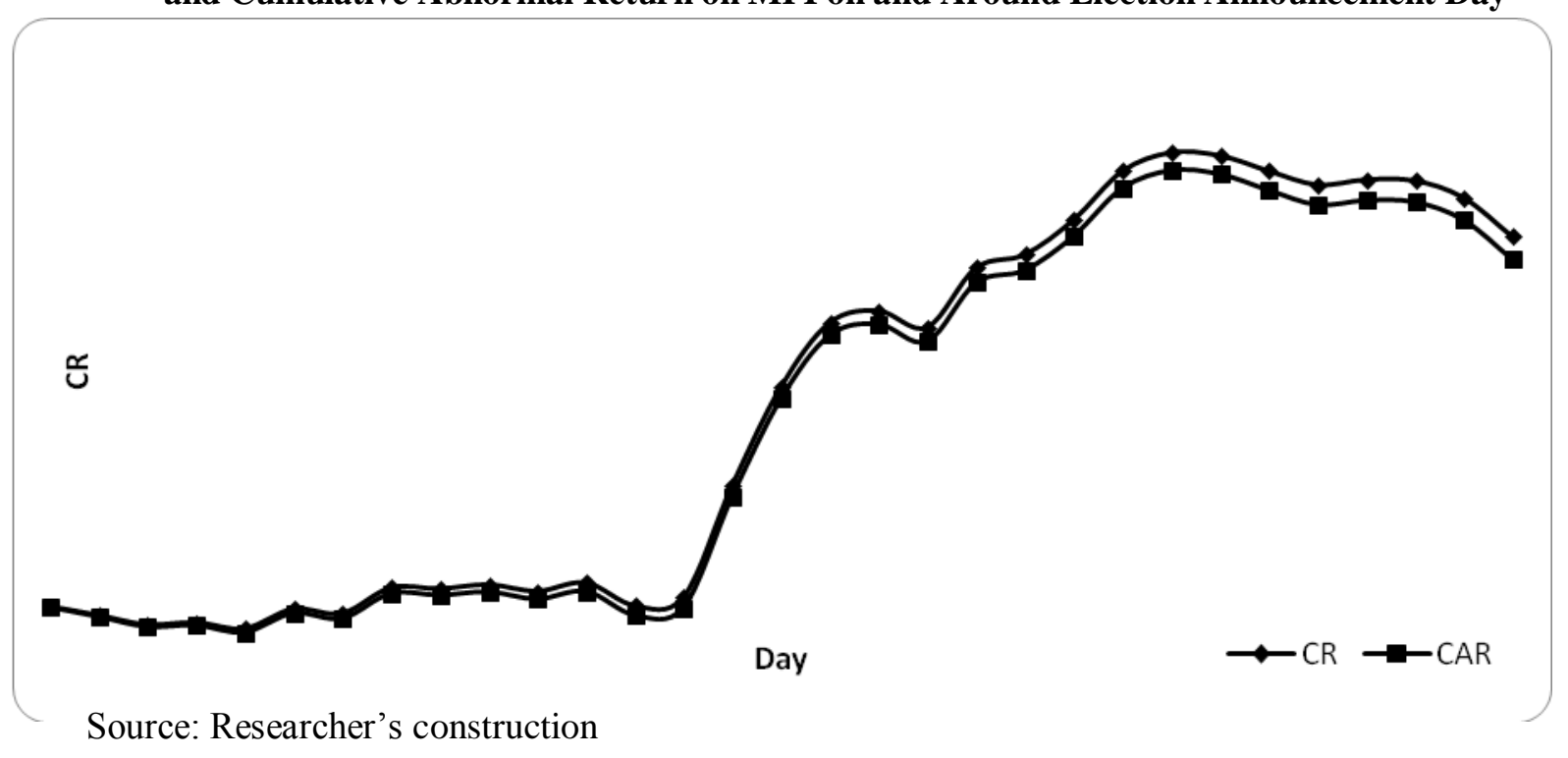


If the announcement of election is taken place under a SLFP dominant government, Market seems to create positive sentiments. According to cumulative abnormal return, market had gained more than 6\% (6.423) in terms of ASPI and more than 8\% (8.813) in terms of MPI within the investigation window in relation to their history. The higher test statistics could be seen on and around the event day showing positive sentiments. According to this speculative behaviour, an investor who is having a prior knowledge about the announcement may buy the stocks well in advance the election announcement in order to sell during the post event window in order to earn profit. If somebody wishes to get out of the market after the announcement; ideally he or she may sell the shares within +1 to +7 days as the market shows a $\mathrm{U}$ turn by day +8 . These conclusions are based on the experience of four such events.

\section{Discussion and Conclusion}

As expected patterns of investor behaviour in relation to two main events of the announcement of election and the announcement of election results seems to be highly related with ideologies and policies of two main opposing camps of political parties. Accordingly, market is in favour of united national political party led regime. This may be due to the fact that the UNP regimes are more market friendly (Mendis, 2003), despite the fact that the policy difference between two parties has got narrowed over the years. On the hand market has not been so favourable towards less market friendly regime. This particular behaviour is very visible in relation to the announcement of elections. Announcement of elections can simply mean either one of the followings.

i. It provides more opportunity for the market or

ii. It provides lesser opportunity for the market

Initial positive response showed by the stock market for the announcements of elections under a less market friendly government shows that market had taken it as an opportunity to make a more market friendly government. Announcements made under more market friendly regimes had been taken negatively by the market. That is due to the fact that announcements of elections under a market friendly government would be taken as a negative event because it gives an opportunity for less market friendly parties to form a new government. This thinking is reflected in the market behaviour whenever UNP led government made an announcement price of securities (stocks) had always shown a negative response because elections give an opening for another party (less market friendly) to come to power. On the other hand, announcement of elections under non UNP regime have been taken positively by the market. It has been taken as a positive event for the market because it gives an opening for a market friendly regime to come to power.

If the announcement of election is taken place under a more market friendly UNP dominant government, market seems to create negative sentiments and within few days of announcement market started to gain profit showing a U turn. According to this speculative behaviour, an investor who is having a prior knowledge about the announcement may sell the stocks well in advance of the election announcement in order to avoid the losses. However soon after the announcement of election, selling seems not to be advisable as market gains profit within few days. If somebody wishes to get out of the market after the announcement; ideally he or she may sell the shares within +2 to +4 days as the higher positive returns belong to this period. If the announcement of election is taken place under a less market friendly SLFP dominant government, market seems to create positive sentiments. 
According to this speculative behaviour, an investor who is having a prior knowledge about the announcement may buy the stocks well in advance the election announcement in order to sell during the post event window in order to earn profit. If somebody wishes to get out of the market after the announcement; ideally he or she may sell the shares within +1 to +7 days as the market shows a $U$ turn by day +8 . If the party was in power prior to the election was more market friendly but the party formed after the election is less market friendly, the election result has been taken negatively in terms of cumulative abnormal return. Within few days, the market seems to gain profit showing a $U$ turn by day +8 . According to this speculative behaviour, an investor who is having a prior knowledge about the result may sell the stocks well in advance the election announcement in order to avoid the losses. However soon after the announcement of election, selling seems not to be advisable as market gains profit within few days. If somebody wishes to get out of the market after the announcement of result; ideally he or she may sell the shares within +8 to +11 days as the higher positive returns belong to this period. If the party was in power prior to the election as well as new party formed after the elections are less market friendly once, the election result has been taken negatively. According to this speculative behaviour, an investor who is having a prior knowledge about the result may sell the stocks well in advance the election announcement in order to avoid the losses. However soon after the announcement of election, panic selling seems not to be advisable as market would gain profit in the future. If the party was in power prior to the election was less market friendly but the party formed after the election was more market friendly, the election result has been taken positively in terms of cumulative abnormal return. An investor who is having a prior knowledge about the result may buy the stocks well in advance the release of election results in order to earn profit after the release of election results.

When the individual elections are analysed since 1991, there is a convergence in the policies introduced by both UNP and SLFP regimes in relation to the stock market. But, still the market communities think that UNP party is market friendly and SLFP is less market friendly; therefore, the market expectation is a UNP regime.

\section{References}

Allvine, F.C., \& Neill, D.E. (1980). Stock Market Returns and the Presidential Election Cycle: Implication for Market Efficiency.Financial Analysis Journal, Sep/Oct.

Beyer, B., Jensen, R.,\& Johnson, R. (2004). Don't Worry About the Election. The Journal of Portfolio Management, 101-108.

Bilson, C.M., Brailsford,T., \& Hooper,V.C. (2002).“The Explanatory Power of Political Risk in Emerging Markets."International Review of Financial Analysis 11, 1-27.

Bittlingmayer, G. (1998). Output, Stock Volatility, and Political Uncertainty in a Natural Experiment: Germany, 1880-1940. Journal of Finance, 53(6), 2243-2258.

Bratsiotis, G. J. (2000). Political Parties and Inflation in Greece: The Metamorphosis of the Socialist Party on the Way to EMU: Applied Economics Letters, 7(7): 451-454.

Chan, Y., \& Wei, J. (1996). Political Risk and Stock Price Volatility: The Case of Hong Kong. Pacific Basin Finance Journal, 4(2-3), 259-275.

Chen. D.H., Bin. F.S., \& Chen, C.D. (2005). The Impacts of Political Events on Foreign Institutional Investors and Stock Returns: Emerging Markets Evidence from Taiwan. International Journal of Business, 10(2), 1083-4346.

Chiu, C.L., Chen, C.D. \& Tang, W.W. (2005). Political Elections and Foreign Investor Trading in 
South Korea's Financial Markets. Applied Economics Letters, 12(11): 673-677.

Dobson, J.,\&Dufrene, U.B. (1993). The impacts of U.S. Presidential elections on international security-markets. Global Finance Journal, 4(1), 39-47.

Easaw, J., \& Garratt, D. (2000). Elections and UK Government Expenditure Cycles in the 1980s: an Empirical Analysis.Applied Economics, 32(3): 381-391.

Fama, E. (1976). Efficient capital markets: reply. Journal of Finance, 3, 143-5.

Forester, S. R. (1994). Stock Market Performance and Elections: Made-in-Canada effects?.

Canadian Investment Review, 7(2), 39-42.

Forester, S.R., \& Schmitz, J.J. (1997). The Transmission of US Election Cycles to International Stock

Returns. Journal of International Business Studies, 28(1), 1-27.

Fred, C. Allvine, \& Daniel, E.O’Neill (1980). Stock Market Returns and the Presidential

Election Cycle. Financial Analysts Journal, 49-56.

Freedman, L. (1997). Economic Crises and Political Change: Indonesia, South Korea, and

Malaysia.American Review, 232-249.

Gemmill,G. (1992). Political Risk and Market Efficiency: Tested Based in British Stock and option

Markets in the 1987 Election.Journal of Banking and Finance, 16(1), 211-231.

Harms, P. (2002).Political Risk and Equity Investment in Developing Countries. Applied Economic Letters, 9(6), 377-80.

Huang, R.D. (1985). Common stock returns and presidential elections. Financial Analysts Journal, 41(2), 58-65.

Johnson, R., Crittenden, W., \& Jenson, G. (1999).Presidential politics, Stocks, Bills, and Inflation.

The Journal of Portfolio Management, 26, 27-31.

Klein, M., Mizrach, B., \& Murphy, G. (1991). Managing the Dollar: Has the Plaza Agreement Mattered? Journal of Money, Credit \& Banking, 742-751.

Lin, C. T., \& Wang, Y.H. (2007). The impact of Party Alternative on the Stock Market: the Case of Japan.Applied Economics,39(1), 79-85.

Lin, C. T., \& Wang, Y.H. (2005). An Analysis of Political Changes on Nikkei 225 Stock Returns and Volatilities. Analysis of Economics and Finance, 6, 169-183.

Lopez. E.J. (2002). The Legislator as Political Entrepreneur: Investment in Political Capital. The Review of Austrian Economics, 15(2/3),211-228.

Mackinlay.C. (1997). Event Studies in Economic and Finance. Journal of Economic

Literature.March.

Niederhoffer, V., Gibbs, S., \& Bullock, J. (1970).Presidential elections and the stock market.

Financial Analysts Journal, Mar/Apr, 111-13.

Niarchos.N.A.,\&Alexakist. C.A.(2003). Intraday stock price patterns in the Greek Stock exchange. Applied Financial Economics, 13, 13-22.

Pantzalis, C., Stangeland. D.A., \& Turtle, H.J. (2000). Political Elections and the Resolution of Uncertainty: The International Evidence. Journal of Banking and Finance, 24(10), 1575-604.

Riley, W. B. \&Luksetich, W.A. (1980). The market prefers Republicans: Myth or reality, Journal of Financial and Quantitative Analysis, 15(3), 541-560.

Samarakoon, L. P (1998). Sri Lankan Stock Market. Publication book that was compiled under technical assistance from the USAID Financial Markets Projects.

Schleifer, A. \& Vishny, R.W. (1997) A survey of corporate governance. Journal of Finance.

Siokis, F., \& Kapopoulus, P. (2003). Parties, Elections, and Stock Market Volatility: Evidence from a Small Open Economy. Economics and Politics, 19(1), 123-133. 
Wang. Y.H., Lee. M.Y. \& Lin. C.Y. (2008). General Election, Political Change and Market Efficiency: Long-and Short-Term perspective in developed stock market. Journal of Money, Investment and Banking.

William, B. Riley, Jr. \& William, A. L. (1980). The Market Prefers Republicans: Myth or Reality. Journal of Financial and Quantitative Analysis, 15(3), 541-560.

Mendis, W. (2003). Contrast of Post- Independence Economic and Physical Planning at a Glance. www.Google.com 